\title{
The Performance of Cucumber Plants (Cucumis sativus L.) as Affected by Organic and NPK Mineral Fertilization under Plastic Houses Conditions at Arid Region

\author{
Alkharpotly, A. A. ; M. N. Shehata and K. G. Abd El Rasheed \\ Hort. Dept., Fac. Agric. \&Natur. Reso., Aswan Univ., Aswan, Egypt
}

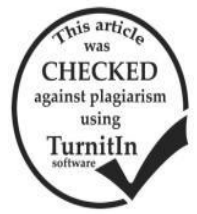

\section{ABSTRACT}

Two plastic house experiments were conducted during 2016/2017 and 2017/2018 seasons in the Experimental Farm, Faculty of Agriculture and Natural Resources, Aswan University, Egypt on a sandy textured soil under unheated plastic houses. The target of fertilization program seeks to achieve the best combination of various organic and NPK mineral fertilization that lead to the highest yield and quality of cucumber plant 'Merage $\mathrm{F}_{1}$ hybrid" especially during the winter season. Therefore, 12 treatments were arranged in a split plot layout in complete randomize block design with three replicates. Chicken manure at the rates of $\left(10,15\right.$ and $20 \mathrm{~m}^{3} / \mathrm{fed}$.) were randomly arranged in the main plots, while NPK mineral fertilization at rates of (0:0:0, 50:30:50, 100:40:80, and 150:50:110 Kg N: $\mathrm{P}_{2} \mathrm{O}_{5}$ : $\mathrm{K}_{2} \mathrm{O} /$ fed., respectively, were randomly distributed in the sub-plots. The obtained results demonstrated that the treatment combination of chicken manure at $20 \mathrm{~m}^{3} /$ fed. plus 150:50:110 kg. NPK/fed. exhibited the highest significant mean values of most studied characters as vegetative growth characters (i.e. number of leaves/plant, the number of branches /plant, plant fresh weight and chlorophyll index); yield characters \{i.e. no. fruits /plant, average fruit weight $(\mathrm{g})$, total yield $/ \mathrm{m}^{2}(\mathrm{~kg})$ and early yield $\left./ \mathrm{m}^{2}(\mathrm{~kg})\right\}$; fruit quality (i.e. TSS \%, vitamin C, and reducing, non-reducing and total sugars); fruits chemical analysis characters ( $\mathrm{viz}, \mathrm{N}, \mathrm{P}, \mathrm{K}$ contents in fruits ) during both seasons of the study as compared to the other treatments. Based upon, the reported results, it is possible to conclude that, the combination among 20 $\mathrm{m}^{3} / \mathrm{fed}$. of chicken manure plus 150:50:110 Kg. NPK/fed. considered as the optimal combination treatment whereas it gave the highest mean values of vegetative growth characters, yield and its components and fruit quality of cucumber plants grown under plastic houses conditions at Aswan governorate and similar regions.

Keywords: cucumber, yield and quality, NPK mineral fertilization, organic fertilization, chicken manure.

\section{INTRODUCTION}

Cucumber (Cucumis sativus L.) is a member of family Cucurbitaceae. It is one of the most popular and favorite vegetable crops cultivated under plastic houses in Egypt and the worldwide. It is a sub-tropical vegetable crop that grows successfully under conditions of high light, high humidity, high soil moisture, temperature and fertilizers in green-house (El-Aidy et al., 2007). In Egypt, it is grown as a summer crop in the open field in the period from March to September, and under plastic house conditions from September to May.

The increase in soil productivity is one of the major key factors, attributing to substantial increase in agricultural production to fulfill the increase in the human population. In order to achieve higher yields and quality, soil health is a critical factor. Therefore, chemical fertilizers must be integrated with organic manures. The yield per unit area can be increased along with the improvement of its quality through the balanced application of organic and inorganic in proper combination. Mineral fertilizers considered a major source of plant nutrition, but the excessive use of mineral fertilizers represent the major cost in plant production and creates pollution of agro-eco system as well as deterioration of soil fertility (Singh and Ryan, 2015).

Despite organic manures are known to improve the soil properties via increasing the limited moisture holding capacity. In addition, they can change the chemical properties of the soil via lowering its $\mathrm{pH}$ among some other factors. Also, they can provide the plants with many essential nutrients as nitrogen, phosphorus or potassium or a combination of these three elements (Haug, 1993 and Elsokkary et al., 1995). On the other tank, the use of manures (organic fertilization) only cannot satisfy the cultivated crop with nutrients (Kondapa et al., 2009; Deore et al., 2010). In spite of the positive potential of compost on yield of food crops its low nutrients content and high cost relative to inorganic fertilizers; makes its use as alone provided nutrient supplies not practical matter (Buchanan and Gliessman, 1991; Bittenbender et al., 1998). Aritonang et al. (2018) found that the highest rate $3 \mathrm{~kg} / \mathrm{plot}$ of chicken manure increases cucumber plant height, number of leaves, fresh fruits weight. However, they may be used in combination with other fertilizers is necessary in order to increase soil organic matter and reduce loss of inorganic $\mathrm{N}$ from the rhizosphere (Roba, 2018).

The mineral nutrients, $\mathrm{N}, \mathrm{P}$ and $\mathrm{K}$ are known to affect growth, yield and quality of the cucumber. Fertilizer requirements of cucumber are quite high due to its high yielding potential per unit area and time. Accordingly, mineral nutrition with suitable levels of nitrogen $(\mathrm{N})$, phosphorus $(\mathrm{P})$ and potassium $(\mathrm{K})$ had a key role for improving the growth, fruit yield and quality of cucumber, as well as influencing the cucumber plant's ability to withstand negative effects from pests, water, temperature, and other stresses (Ngwul and Edeh, 2018). However, generally, excessive amount of mineral fertilization are applied to vegetables to achieve higher yield (Deore et al., 2010) and enhance the growth (Dauda et al., 2008). Also, using of inorganic fertilization only may lead to risks not only for human beings' health, but also for environment, too (Arisha and Bradisi, 1999). Nevertheless, $\mathrm{N}$ along with $\mathrm{P}$ and $\mathrm{K}$, are, still, classified as primary macronutrients or major nutritive elements, which are needed in relatively large quantities and are often deficient in crops not receiving fertilizer application (Marschner, 1995).

Improved nitrogen management can be achieved by matching nitrogen supply with crop need and selecting appropriate nitrogen level to minimize nitrate nitrogen accumulation in soil at times, when the leaching potential is high (Papendick, 1987). Under severe conditions of excess nitrogen, leaves developed necrotic lesions followed by dropping.

It is evident from literature, that potash affects mostly the quality of fruits and vegetables. Potassium is one of the three major nutrients needed for plant growth (Russo, 1991; Hartz et al., 1993). Potassium plays a part in many important regulatory roles in the plant, i.e. osmo-regulation process, regulation of plant stomata and water use, translocation of sugars and formation of carbohydrates, energy status of the plant, the regulation of enzyme activities, protein synthesis and many other processes needed to sustain plant growth 
and reproduction (Hsiao and Lauchli, 1986). It is, also, a highly mobile element in the plant and has a specific phenomenon, it is called luxury consumption. Potassium is, also, known as the quality nutrient because of its important effects on quality factors (Lester, 2006). Further, phosphour plays a central, pivotal metabolic and regulatory role on the many of several physiological and biochemical processes in plants, including photosynthesis, energy conservation, interand intracellular co-ordination of carbohydrate metabolism and in energy transfers (Abel et al., 2002).

Nowadays, the best integrated fertilization management which includes inorganic and organic fertilization; plays crucial roles in this respect. Therefore, the absence of fertilization program for cucumber production under plastic houses conditions at arid remains limiting factor, needs more research to develop an appropriate fertilization program satisfies the requirements to achieve the highest yield with best quality of cucumber plants grown under plastic houses environments. So, the objectives of these experiments were to examine the beneficial roles of organic and mineral (NPK) fertilization on cucumber (Cucumis sativus L.) growth performance under plastic houses conditions to determinate the suitable fertilization program to cucumber plants 'Merage $\mathrm{F}_{1}$ hybrid' growing at arid conditions.

In this respect, Dash et al. (2018) found that application of half recommended dose NPK + FYM at 10 t/ha + Vermicompost at $2 \mathrm{t} / \mathrm{ha}+$ Biofertilizer $(4.0 \mathrm{~kg}$ Azotobacter/ha+ $4.0 \mathrm{~kg} \mathrm{PSB} / \mathrm{ha}$ ) recorded the highest cucumber fruit weight, average fruit weight and highest yield. Also, Singh et al. (2018) reported that application of $75: 45: 45 \mathrm{~kg} / \mathrm{ha}$ NPK + 1.875 ton/ha farm yard manure + 1.25 ton/ha vermicompost had a beneficial effect on growth parameters like maximum vine length, number of leaves plant $^{-1}$, maximum number of primary branches plant ${ }^{-1}$, maximum length and width of leaf, flowering parameters viz. minimum days to first flower formation, minimum number of days to first male and female flower formation, lowest number of male flowers plant ${ }^{-1}$, maximum number of female flowers plant ${ }^{-1}$, lowest sex ratio and yield and yield attributing characters like minimum days taken to first fruit formation, maximum number of fruits plant ${ }^{-1}$, length of fruit, width of fruit, weight of fruit, maximum fruit yield plant $^{-1}$, fruit yield plot $^{-1}$, highest fruit yield, maximum TSS of edible fruit and peel thickness as compared to control. Abdel Naby et al. (2014) illustrated that a combination of chicken manure at rate of $15 \mathrm{~m}^{3} / \mathrm{fed}$. with foliar spraying of yeast extract at rate of $5 \mathrm{~g} / \mathrm{l}$ and mineral fertilizers with ammonium nitrate $(33.5 \% \mathrm{~N})$ at $125 \mathrm{~kg} / \mathrm{fed}$; increase cantaloupe yield which surpassed the control plants. Feleafel et al. (2014) demonstrated that using of NPK as fertigation, up rate $125 \%$ of recommended dose; $\left(220,150,150 \mathrm{~kg} \mathrm{~N}, \mathrm{P}_{2} \mathrm{O}_{5}, \mathrm{~K}_{2} \mathrm{O} / \mathrm{ha}\right.$, respectively) brought about significant increases for leaves number after 30, 50 and 70 days of sowing seeds, branches number at 30 days of sowing seeds, also leaf minerals (N, P and $\mathrm{K}$ ) contents, , fruit weight, fruits' number and yield of fruits of the greenhouse cucumber plants, cv. 'Alrased 92 F1'. Anjanappa et al. (2012) illustrated that the cucumber "Hassan" cv. plants grown under plastic house and fertilized with $75 \%$ recommended dose (60:50:80 kg NPK/ha) $+75 \%$ from recommended farm yard manure $(2.5$ t/ha) + Azotobacter (AZT) $5 \mathrm{~kg} / \mathrm{ha}+$ Phosphobacteria (PSB) $5 \mathrm{~kg} / \mathrm{ha}$ + Trichoderma (TD) $5 \mathrm{~kg} / \mathrm{ha}$; recorded the maximum number of branches per vine, least number of days elapsed until the first male and female flower appearance, highest number fruits per vine, maximum fruit weight and maximum fruit yield per vine.

While the lowest number of fruits per vine and lowest fruit weight was registered with treatment provided with $100 \% \mathrm{FYM}+\mathrm{AZT}+\mathrm{PSB}+\mathrm{TD}$. Bindiya et al. (2006) revealed that combined application of vermicompost ( $2 \mathrm{t} / \mathrm{ha})$ + half recommended NPK (50:30:30 kg/ha) + Azotobacter and phosphate solubilizing bacteria (PSB) each at $5 \mathrm{~kg} / \mathrm{ha}$; gave rise to increase number of branches per vine, showed quicker earliness and days to 50 percent flowering of the tested cucumber cultivar and gave ultimately higher yield of cucumber fruits.

\section{MATERIALS AND METHODS}

Two field experiments were carried out during the winter seasons of 2016-2017 and 2017-2018, at the Experimental Station Farm, Faculty of Agriculture and Natural Resources, Aswan University, Egypt, under unheated plastic houses. Before transplanting, random soil sample of 0$30 \mathrm{~cm}$ depth from different places of the greenhouse were collected and analyzed for some important chemical and physical properties as given in Table (1) according to Wilde et al., 1985. Cucumber seeds were sown under plastic house on October $26^{\text {th }}$, during both seasons, in seedling foam trays (84 eyes) filled with a mixture of Peat moss: Vermiculite $(1: 1 \mathrm{v} / \mathrm{v})$, supplemented with $300 \mathrm{~g}$ Ammonium Sulphate $(20.5 \% \mathrm{~N}), 400 \mathrm{~g}$ Calcium Superphosphate $\left(15 \% \mathrm{P}_{2} \mathrm{O}_{5}\right), 150$ $\mathrm{g}$ Potassium Sulphate $\left(48 \% \quad \mathrm{~K}_{2} \mathrm{O}\right), 50 \mathrm{~g}$ micronutrient solution and $50 \mathrm{~g}$ of a fungicide (Thiophanate Methyl) for each $50 \mathrm{~kg}$ of the mixture.

Seedlings of 25 days old were transplanted in the plastic houses on November $20^{\text {th }}$ during both seasons at 30 $\mathrm{cm}$ apart and $1 \mathrm{~m}$ width of ridge. The experimental plot consisted of one ridge with $3 \mathrm{~m}$ long and 1 meter width making an area of $3 \mathrm{~m}^{2}$ under drip irrigation system. All missing transplants were replaced by another ones of the same age, one week later after transplanting. The plastic house was $24 \mathrm{~m}$ long and $6 \mathrm{~m}$ width making a total area 144 $\mathrm{m}^{2}$, during both seasons, $50 \mathrm{~cm}$ from both sides of the plastic house's arch near from plastic and $30 \mathrm{~cm}$ from beginning (entrance) and end (exit or out) of the plastic house were left without planting. So, the total number of plants/ plastic house were 315 plants $\left(2.71\right.$ plants $\left./ \mathrm{m}^{2}\right)$.

Cucumber cultivar' seeds coined as 'Merage F1 hybrid' was used for the experimentation. It was purchased form Top Seeds for Agriculture Co., Egypt.

Organic fertilization was done using matured chicken manure which obtained from the local area and its chemical analysis is presented in Table (2). Chicken manure treatments were randomly assigned in the main plots as 10,15 and 20 $\mathrm{m}^{3} /$ fed. before planting. Mineral fertilization treatments were randomly distributed in the sub plots as $(0-0-0,50-30-50$, $100-40-80$, and 150-50-110 Kg N-P $\mathrm{O}_{5}-\mathrm{K}_{2} \mathrm{O} /$ fed., respectively. Ammonium nitrate $(33.5 \% \mathrm{~N})$ and nitric acid $(15 \% \mathrm{~N})$ as a source of nitrogen were added. Phosphoric acid $\left(55 \% \mathrm{P}_{2} \mathrm{O}_{5}\right)$ as a source of phosphorus was used. In addition, soluble potassium sulphate $\left(50 \% \mathrm{~K}_{2} \mathrm{O}\right)$ as a source of potassium was added and calcium nitrate $(15.5 \% \mathrm{~N}+19 \%$ $\left.\mathrm{Ca}_{2} \mathrm{O}\right)$ as a source of nitrogen and calcium was applied. The ratios among the three-used mineral fertigation were distributed according to plant growth periods as listed in Table (3). A drip irrigation network was designed for this study and consisted of lateral's GR of $16 \mathrm{~mm}$ in diameter, 
with emitters at $0.3 \mathrm{~m}$ distance, with allocating a lateral for each row. The emitters had a discharge rate of $41 . h^{-1}$. Both conducted experiments were split plot layout in a randomized complete blocks design, with three replications, each replicate included 12 treatments.

Table 1. Some physical and chemical properties of the experimental site during both seasons 2016/ 2017 and 2017/2018.

\begin{tabular}{|c|c|c|}
\hline \multirow{2}{*}{$\begin{array}{l}\text { Soil } \\
\text { properties }\end{array}$} & \multicolumn{2}{|c|}{ Season } \\
\hline & $2016 / 2017$ & $2017 / 2018$ \\
\hline \multicolumn{3}{|l|}{ Mechanical Analysis: } \\
\hline Clay $(\%)$ & 4.00 & 4.50 \\
\hline Silt $(\%)$ & 3.00 & 3.00 \\
\hline Sand (\%) & 93.00 & 92.50 \\
\hline Textural class & Sandy & Sandy \\
\hline \multicolumn{3}{|l|}{ Chemical Analysis: } \\
\hline pH (1:2 water suspension) & 7.60 & 7.70 \\
\hline $\mathrm{EC}$ at $25^{\circ} \mathrm{C}(\mathrm{dS} / \mathrm{m})$ & 0.25 & 0.28 \\
\hline \multicolumn{3}{|c|}{ Soluble cations in (1:5) soil: water extract (meq/l) } \\
\hline $\mathrm{Ca}^{++}$ & 3.06 & 3.10 \\
\hline $\mathrm{Mg}^{++}$ & 1.02 & 1.05 \\
\hline $\mathrm{K}^{+}$ & 0.83 & 0.85 \\
\hline $\mathrm{Na}^{+}$ & 0.76 & 0.80 \\
\hline \multicolumn{3}{|c|}{ Soluble anions in (1:5) soil: water extract (meq/l) } \\
\hline $\mathrm{CO}_{3}^{--}$ & 0.00 & 0.00 \\
\hline $\mathrm{HCO}_{3}^{-}$ & 7.10 & 7.06 \\
\hline $\mathrm{Cl}^{-}$ & 3.60 & 3.57 \\
\hline $\mathrm{SO}_{4}^{--}$ & 0.40 & 0.44 \\
\hline Available N (mg/kg soil) & 10 & 15 \\
\hline Available P (mg/kg soil) & 31 & 37 \\
\hline Available K (mg/kg soil) & 175 & 180 \\
\hline \multicolumn{3}{|c|}{$\begin{array}{l}\text {-The physical and chemical analyses were carried out at Soil anc } \\
\text { Agricultural Chemistry Departement, The Faculty of Agricultu } \\
\text { (Saba Basha), Alexanderia University, Egypt. }\end{array}$} \\
\hline \multicolumn{3}{|c|}{$\begin{array}{l}\text { Table 2. Chemical analysis of the chicken manure of } \\
\text { both seasons } 2016 / 2017 \text { and } 2017 / 2018 \text {. }\end{array}$} \\
\hline \multirow{2}{*}{ Properties } & \multicolumn{2}{|c|}{$\begin{array}{l}\text { Season } \\
\end{array}$} \\
\hline & 2016/2017 & $2017 / 2018$ \\
\hline $\begin{array}{l}\mathrm{pH}(1: 10 \text { manure suspension) } \\
\end{array}$ & 7.52 & 7.50 \\
\hline EC $(1: 10)$ water extract $(\mathrm{dS} / \mathrm{m})$ & 3.90 & 3.80 \\
\hline O. M. \% & 59.31 & 59.25 \\
\hline \multicolumn{3}{|l|}{ Soluble cations (meq/l) } \\
\hline $\mathrm{Ca}^{++}$ & 3.10 & 3.00 \\
\hline $\mathrm{Mg}^{++}$ & 2.72 & 2.75 \\
\hline \multicolumn{3}{|l|}{ Available nutrients (\%) } \\
\hline Nitrogen $(\mathrm{N})$ & 2.28 & 2.25 \\
\hline Phosphours (P) & 1.05 & 1.08 \\
\hline Potassium (K) & 1.75 & 1.65 \\
\hline $\mathrm{C} / \mathrm{N}$ ratio & 13:1 & 13:1 \\
\hline
\end{tabular}

Table 3. Chemical fertilization program as a ratio among $\mathrm{N}: \mathrm{P}_{2} \mathrm{O}_{5}: \mathrm{K}_{2} \mathrm{O}$

\begin{tabular}{lcccc}
\hline $\begin{array}{l}\text { Fertilization } \\
\text { period }\end{array}$ & $\begin{array}{c}\text { \% From total } \\
\text { amount }\end{array}$ & $\mathbf{N}$ & $\mathbf{P}_{\mathbf{2}} \mathbf{O}_{\mathbf{5}}$ & $\mathbf{K}_{\mathbf{2}} \mathbf{O}$ \\
\hline Till flowering & 30 & 3.00 & 1.00 & 2.00 \\
Till the harvesting & 40 & 3.00 & 1.50 & 3.00 \\
Till the end of harvesting & 30 & 3.00 & 1.50 & 3.00 \\
\hline
\end{tabular}

Cucumber plants were trained vertically on single stem, where all lateral branches were removed from both cotyledonary leaves until the second true leaf. After that, the all lateral branches were cut off after two leaves (two fruits) until $2 \mathrm{~m}$ height till the end of the growing seasons. Harvesting of the fruits was done for early yield after 40 days, then for the rest of harvesting, daily in summers and each 2 days in winter seasons.

Four plants form each treatment in each replications were randomly selected for records on growth, early yield and total yield as well fruit quality parameters.
1. Vegetative growth characters: all the following characters were determined after 120 days from transplants: number of leaves per plant, number of branches per plant, plant fresh weight $(\mathrm{g})$ as the average fresh weight of plant foliage (leaves and stem) and Leaf colour degrees or Leaf chlorophyll indication (SPAD), for determination chlorophyll readings, at harvest, leaf greenness (chlorophyll content ) was done using a non- destructive method using a SPAD 502 chlorophyll meter for each plant, 3 recently full- expanded leaves were randomly chosen for SPAD measurement at the average of 3 readings was recoded (Yadva, 1986; Marquard and Tipton, 1987).

2. Fruit number and yield parameters, were determined via number of fruits per plant was determined from the total number of fruits harvested over the entire harvest period (130 days), average fruit weight (g), fruit yield per square meter $\left(\mathrm{kg} / \mathrm{m}^{2}\right)$ and Early yield was considered as the weight of all harvested fruits during the first 40 days of harvesting per square meter $(\mathrm{kg})$.

3. Fruit quality, four fruits were randomly taken from each plot of all pickings to study the chemical fruit quality characters in both seasons as follows (1): The total soluble solids (T.S.S.) was estimated in the juice of the fresh fruits using a hand refractometer according to (A.O.A.C., 1992). (2) Vitamin C (Ascorbic acid), was measured by titration with iodide potassium according to method of Ranganna (1986) and calculated as mg vitamin $\mathrm{C} / 100 \mathrm{~cm}^{3}$ juice. (3) Total, reducing and non-reducing sugars, which were determined according to the method described by Malik and Singh (1980) and (4)

4. Fruits chemical composition, fruit nitrogen content (\%) was determined colorimetrically by Nessler's method (Chapman and Pratt, 1978). Fruit phosphorus content (\%) was determined colorimetrically as described by Singh et al. (2005). Fruit potassium content (\%) was measured using flame photometer as described by Singh et al. (2005).

\section{Statistical Analysis:}

All obtained data of the present study were, statistically, analyzed according to the design used by the MSTAT-C computer software program (Bricker, 1991) and were tested by analysis of variance. The comparisons among the means of different treatments were carried out, using the revised least significant difference test at 0.05 level of probability as illustrated by (Duncan, 1965; Gomez and Gomez, 1984).

\section{RESULTS AND DISCUSSION}

\section{Vegetative growth characters:}

As for the main effect of organic fertilization, average values listed in Table (4) indicated that applied chicken manure at rate of $20 \mathrm{~m}^{3} / \mathrm{fed}$. brought about the highest significant average values for number of leaves/plant, number of branches/plant and chlorophyll index reading by SPAD during both seasons and for plant fresh weight character during the second season only.

In terms of the main effect of mineral fertilization, the postulated results showed clearly that cucumber plants fertilized with highest rate of $\mathrm{N}: \mathrm{P}_{2} \mathrm{O}_{5}: \mathrm{K}_{2} \mathrm{O}$ (150:50:110) gave, significantly, highest average values of number of leaves/plant, number of branches/plant, plant fresh weight and chlorophyll index reading by SPAD compared with the other treatments during both seasons. 
Concerning the interaction effects, the obtained results showed that the highest significant average values of vegetative growth characters (i.e. number of leaves/plant, the number of branches /plant and chlorophyll index) were obtained from the treatment combination of chicken manure at $20 \mathrm{~m}^{3} /$ fed. plus 150:50:110 Kg. NPK/fed. compared to the other treatments during both seasons. The obtained results, in this context, show that the integrated role of the tested combinations on the given traits, i. e. the balanced and better nutrition absorbed and metabolize of more carbohydrate by plants due to providing them with the best combination of nutrition's, which could provide quick release of mineral NPK elements plus those being slowly released via organic fertilization which could enhance vegetative growth (Adhikari et al., 2016). The result of physical and chemical properties of the soil (Table 1) indicated that the soil textural class was a sandy, containing $4.25 \%$ clay, 3\% silt and $92.75 \%$ sand (as an average of both seasons). Therefore, increases in the vegetative growth of cucumber plants by applying chicken manure might be referred to its role in enhancing soil physical properties as soil texture, water holding capacity and it creates a good aeration in soils and decreased the $\mathrm{pH}$ value and consequently nutrients in the soil became more available for enhancing plant growth. It, also, includes some plant growth promoters such as auxins and gibberellic acid. This result is in agreement with Anjanappa et al. (2012); Feleafel et al. (2014). This finding may be, also, attributed to the critical part of $\mathrm{N}$ in plants, which found in nucleic acids, co-enzymes, and proteins- phosphorus, likewise has a part in $\mathrm{N}_{2}$ fixation, and increment photosynthesis of plant, although phosphorus has a fundamental part in energy metabolism the high energy of hydrolysis of phosphate and different organic phosphate bonds being used to induce chemical reaction, while potassium activates some enzymes and $\mathrm{K}^{+}$ions play an vital part in control leaves stomatal guard cells and as well increment photosynthesis.

Table 4. Average values of some vegetative growth characters of cucumber plants 'Merage F1' as affected by organic, NPK mineral fertilizers and their interaction during 2016/2017 and 2017/2018 growing seasons.

\begin{tabular}{|c|c|c|c|c|c|c|c|c|c|}
\hline \multirow{2}{*}{$\begin{array}{l}\text { Treatments } \\
\text { (Fertilizers) }\end{array}$} & & \multicolumn{2}{|c|}{$\begin{array}{c}\text { No. } \\
\text { of leaves/ plant }\end{array}$} & \multicolumn{2}{|c|}{$\begin{array}{c}\text { No. } \\
\text { branches/plant }\end{array}$} & \multicolumn{2}{|c|}{$\begin{array}{l}\text { Plant fresh } \\
\text { Weight }(g)\end{array}$} & \multicolumn{2}{|c|}{$\begin{array}{c}\text { Chlorophyll index } \\
\text { (reading by (SPAD) units }\end{array}$} \\
\hline & & $2016 / 2017$ & $2017 / 2018$ & $2016 / 2017$ & $2017 / 2018$ & $2016 / 2017$ & $2017 / 2018$ & $2016 / 2017$ & $2017 / 2018$ \\
\hline \multicolumn{10}{|c|}{ Organic fertilizer (main effect) } \\
\hline $10 \mathrm{~m}^{3}$ & & $98.58 \mathrm{C}$ & $101.80 \mathrm{C}$ & $24.08 \mathrm{C}$ & $24.75 \mathrm{C}$ & $1052 \mathrm{C}$ & $1028 \mathrm{~B}$ & $45.09 \mathrm{C}$ & $41.33 \mathrm{C}$ \\
\hline & & $102.80 \mathrm{~B}$ & $104.70 \mathrm{~B}$ & $25.92 \mathrm{~B}$ & $31.58 \mathrm{~B}$ & $1153 \mathrm{~A}$ & $1105 \mathrm{AB}$ & $47.08 \mathrm{~B}$ & $43.97 \mathrm{~B}$ \\
\hline & & $105.10 \mathrm{~A}$ & $106.60 \mathrm{~A}$ & $29.67 \mathrm{~A}$ & $35.58 \mathrm{~A}$ & $1100 \mathrm{~B}$ & $1249 \mathrm{~A}$ & $49.25 \mathrm{~A}$ & $45.98 \mathrm{~A}$ \\
\hline \multicolumn{10}{|c|}{$\mathrm{N}: \mathrm{P}_{2} \mathrm{O}_{5}: \mathrm{K}_{2} \mathrm{O}$ mineral fertilizer (main effect) } \\
\hline 0:0:0 & & $91.11 \mathrm{D}$ & $92.78 \mathrm{D}$ & $21.00 \mathrm{C}$ & $21.11 \mathrm{D}$ & $823 \mathrm{D}$ & $882 \mathrm{C}$ & $40.46 \mathrm{D}$ & $39.78 \mathrm{D}$ \\
\hline $50: 30: 50$ & & $103.70 \mathrm{C}$ & $105.40 \mathrm{C}$ & $23.56 \mathrm{~B}$ & $31.67 \mathrm{C}$ & $1144 \mathrm{C}$ & $1121 \mathrm{~B}$ & $47.00 \mathrm{C}$ & $41.70 \mathrm{C}$ \\
\hline & & $60 \mathrm{~B}$ & $108.80 \mathrm{~B}$ & $3 \mathrm{~A}$ & $34 .($ & $1209 \mathrm{~B}$ & $1165 \mathrm{~B}$ & $49.78 \mathrm{~B}$ & $45.11 \mathrm{~B}$ \\
\hline & & $108.20 \mathrm{~A}$ & $110.30 \mathrm{~A}$ & $31.33 \mathrm{~A}$ & $35.78 \mathrm{~A}$ & $1228 \mathrm{~A}$ & $1342 \mathrm{~A}$ & $51.33 \mathrm{~A}$ & $48.44 \mathrm{~A}$ \\
\hline \multicolumn{10}{|c|}{ Interaction effects } \\
\hline Organic $\mathrm{m}^{3} /$ fed. & & & & & $\mathrm{P}_{2} \mathrm{O}_{5}: \mathrm{K}_{2} \mathrm{O}$ & & & & \\
\hline \multirow{4}{*}{10} & & $83.33 \mathrm{G}$ & $85.67 \mathrm{H}$ & $19.00 \mathrm{H}$ & $17.67 \mathrm{E}$ & $772 \mathrm{~J}$ & $850 \mathrm{D}$ & $37.70 \mathrm{G}$ & $36.33 \mathrm{G}$ \\
\hline & $50: 30: 50$ & $101.00 \mathrm{E}$ & $104.30 \mathrm{~F}$ & $21.67 \mathrm{FG}$ & $25.00 \mathrm{D}$ & $1063 \mathrm{G}$ & 1055 B-D & $45.33 \mathrm{EF}$ & $39.33 \mathrm{~F}$ \\
\hline & $100: 40: 80$ & $104.00 \mathrm{D}$ & $108.00 \mathrm{CD}$ & $27.67 \mathrm{DE}$ & $26.00 \mathrm{D}$ & $1182 \mathrm{E}$ & 1078 B-D & $48.00 \mathrm{CD}$ & $42.63 \mathrm{DE}$ \\
\hline & 150 & $106.00 \mathrm{CD}$ & 109.00 BC & $28.00 \mathrm{DE}$ & $30.33 \mathrm{C}$ & $1190 \mathrm{D}$ & $1130 \mathrm{BC}$ & 49.33 B-D & $47.00 \mathrm{~B}$ \\
\hline \multirow{4}{*}{15} & & & & GH & & $840 \mathrm{I}$ & $895 \mathrm{CD}$ & $40.00 \mathrm{G}$ & $40.33 \mathrm{~F}$ \\
\hline & 50:30: & $104.00 \mathrm{D}$ & $105.70 \mathrm{EF}$ & $23.00 \mathrm{FG}$ & $34.00 \mathrm{~B}$ & $1215 \mathrm{C}$ & $1140 \mathrm{BC}$ & $47.00 \mathrm{DE}$ & $42.17 \mathrm{E}$ \\
\hline & $100: 40$ & $104.70 \mathrm{D}$ & 107.70 C-E & $31.00 \mathrm{BC}$ & $36.00 \mathrm{~B}$ & $1270 \mathrm{~B}$ & 1225 B & $50.33 \mathrm{BC}$ & $45.37 \mathrm{C}$ \\
\hline & $150: 5$ & $108.30 \mathrm{AB}$ & $109.00 \mathrm{BC}$ & $29.00 \mathrm{CD}$ & $36.00 \mathrm{~B}$ & $1285 \mathrm{~A}$ & $1160 \mathrm{~B}$ & $51.00 \mathrm{~B}$ & $48.00 \mathrm{~B}$ \\
\hline \multirow{4}{*}{20} & $0: 0: 0$ & $96.00 \mathrm{~F}$ & $96.33 \mathrm{G}$ & $23.33 \mathrm{~F}$ & $25.33 \mathrm{D}$ & $858.3 \mathrm{H}$ & $900 \mathrm{CD}$ & $43.67 \mathrm{~F}$ & $42.67 \mathrm{DE}$ \\
\hline & $50: 30: 50$ & $106.00 \mathrm{CD}$ & $106.30 \mathrm{D}-\mathrm{F}$ & $26.00 \mathrm{E}$ & $36.00 \mathrm{~B}$ & $1155 \mathrm{~F}$ & $1168 \mathrm{~B}$ & 48.67 B-D & $43.60 \mathrm{D}$ \\
\hline & & $108.00 \mathrm{BC}$ & $110.70 \mathrm{~B}$ & $32.33 \mathrm{~B}$ & $40.00 \mathrm{~A}$ & $1177 \mathrm{E}$ & $1192 \mathrm{~B}$ & $51.00 \mathrm{~B}$ & $47.33 \mathrm{~B}$ \\
\hline & $150: 50: 110$ & $110.30 \mathrm{~A}$ & $113.00 \mathrm{~A}$ & $37.00 \mathrm{~A}$ & $41.00 \mathrm{~A}$ & $1208 \mathrm{C}$ & $1736 \mathrm{~A}$ & $53.67 \mathrm{~A}$ & $50.33 \mathrm{~A}$ \\
\hline
\end{tabular}

Values having the same alphabetical letter (s) in common, within each column, do not significantly differ, using the revised L.S.D. test at 0.05 level of probability.

The findings of chlorophyll could be giving rise to the beneficial effects of each component of the give combination. Chicken manure contains major nutrient. elements associated of photosynthetic activities as $\mathrm{Mg}^{+2}, \mathrm{~N}$, $\mathrm{P}, \mathrm{K}$ and thus cooperate with the other variables in promoting roots and vegetative growth, and the very close relationship between chlorophyll and nitrogen content especially in mineral (inorganic) forms (Field and Mooney, 1986; Amalitois et al., 2004).

It is an acceptable finding owing to considering nitrogen as a structural element of chlorophyll and protein molecules, thereby affects the formation of chloroplasts and accumulation within or inside them (Tucker, 2004; Daughtry et al., 2000). These findings may be taken place owing to the availability of various sources for nitrogen (mineral and organic) containing $\mathrm{N}$ which is involved in biosynthesis of various amino acids, hence proteins function as a structural of chloroplast (Marschner, 1995), subsequently its favorable impact on chlorophyll content is quite expected. The promotive impact of organic and inorganic fertilizer on chlorophyll content may give rise to the fact that $\mathrm{N}$ is a component of chlorophyll molecule.

\section{Yield and its components:}

With reference to the main effect of organic fertilizer (Table 5), it exerted significant $(p \leq 0.05)$ effect on the characteristics under the study, in general. It is noticeable that there is a direct proportionate relationship between the chicken manure application and the given traits. In other words, as chicken manure increases; the given traits' average values increase and vice versa; whereas, the highest rates of chicken manure $\left(20 \mathrm{~m}^{3} / \mathrm{fed}\right.$.) brought about the highest average values for number of fruits/plant, average fruit fresh weight, total yield/square meter and early yield/square meter, compare to the other treatments during both seasons. 
Pertaining the main effect of mineral fertilization, the gained results illustrated that during both growing seasons, cucumber plants treated with $\mathrm{N}: \mathrm{P}_{2} \mathrm{O}_{5}: \mathrm{K}_{2} \mathrm{O}$ at the highest rates (150:50:110 kg/fed.) produced the highest significant average values for number of fruits/plant, average fruit fresh weight, total yield/square meter and early yield/square meter, compare to the other treatments during both seasons.

Concerning the interaction effects between organic and mineral fertilization, the results disclose that the combination of organic manure (chicken) at $20 \mathrm{~m}^{3} /$ fed. plus 150:50:110 Kg. NPK/fed.; recorded the highest average values of number of fruits/plant, average fruit fresh weight, total yield/square meter and early yield/square meter, during both seasons of the study, compare to the other treatments. The results obtained could be attributed to the great vegetative growth which taken place initially due to the enrich nutrient status of the plants which reflected on the production of higher number of fruits/plant and highest average fruit weight which were positively contributes towards fruit's yield. Increased yield was correlated to balanced nutrition, better uptake of nutrients by plants which exerted such good yield.

Table 5. Average values of some yield characters of cucumber plants 'Merage F1' as affected by organic, NPK mineral fertilizers and their interaction during 2016/2017 and 2017/2018 growing seasons.

\begin{tabular}{|c|c|c|c|c|c|c|c|c|c|}
\hline \multirow{2}{*}{$\begin{array}{l}\text { Treatments } \\
\text { (Fertilizers) }\end{array}$} & & \multicolumn{2}{|c|}{$\begin{array}{c}\text { No. of fruits } \\
\text { per plant }\end{array}$} & \multicolumn{2}{|c|}{$\begin{array}{c}\text { Average fruit fresh } \\
\text { weight (g) }\end{array}$} & \multicolumn{2}{|c|}{$\begin{array}{c}\text { Total yield } / \mathrm{m}^{2} \\
(\mathrm{~kg})\end{array}$} & \multirow{2}{*}{\multicolumn{2}{|c|}{$\begin{array}{c}\begin{array}{c}\text { Early yield/m² } \\
\text { (kg) }\end{array} \\
2016 / 20172017 / 2018 \\
\end{array}$}} \\
\hline & & 2016/2017 & $2017 / 2018$ & $2016 / 2017$ & $2017 / 2018$ & $2016 / 2017$ & $2017 / 2018$ & & \\
\hline \multicolumn{10}{|c|}{ Organic fertilizer (main effect) } \\
\hline $10 \mathrm{~m}^{3} / \mathrm{fed}$. & & $48.58 \mathrm{C}$ & $50.08 \mathrm{C}$ & $90.00 \mathrm{~B}$ & $92.75 \mathrm{C}$ & $11.94 \mathrm{C}$ & $12.73 \mathrm{C}$ & $2.99 \mathrm{C}$ & $3.18 \mathrm{C}$ \\
\hline $15 \mathrm{~m}^{3} / \mathrm{fed}$. & & $50.67 \mathrm{~B}$ & $51.92 \mathrm{~B}$ & $91.17 \mathrm{~B}$ & $96.17 \mathrm{~B}$ & $12.59 \mathrm{~B}$ & $13.65 \mathrm{~B}$ & $3.15 \mathrm{~B}$ & $3.41 \mathrm{~B}$ \\
\hline & & $51.25 \mathrm{~A}$ & $54.58 \mathrm{~A}$ & $94.58 \mathrm{~A}$ & $97.83 \mathrm{~A}$ & $13.21 \mathrm{~A}$ & $14.64 \mathrm{~A}$ & $3.30 \mathrm{~A}$ & $3.66 \mathrm{~A}$ \\
\hline \multicolumn{10}{|c|}{$\mathrm{N}: \mathrm{P}_{2} \mathrm{O}_{5}: \mathrm{K}_{2} \mathrm{O}$ mineral fertilizer (main effect) } \\
\hline 0:0:0 & & $42.11 \mathrm{D}$ & $42.89 \mathrm{D}$ & 85.78 D & $82.56 \mathrm{D}$ & $9.79 \mathrm{D}$ & $9.60 \mathrm{D}$ & $2.45 \mathrm{D}$ & $2.40 \mathrm{D}$ \\
\hline 50:30:50 & & $46.89 \mathrm{C}$ & $53.11 \mathrm{C}$ & $88.89 \mathrm{C}$ & $86.89 \mathrm{C}$ & $11.30 \mathrm{C}$ & $12.52 \mathrm{C}$ & $2.82 \mathrm{C}$ & $3.13 \mathrm{C}$ \\
\hline & & $53.56 \mathrm{~B}$ & $55.22 \mathrm{~B}$ & $95.22 \mathrm{~B}$ & $104.60 \mathrm{~B}$ & $13.82 \mathrm{~B}$ & $15.66 \mathrm{~B}$ & $3.46 \mathrm{~B}$ & $3.91 \mathrm{~B}$ \\
\hline & & $58.11 \mathrm{~A}$ & $57.56 \mathrm{~A}$ & $97.78 \mathrm{~A}$ & $108.30 \mathrm{~A}$ & $15.40 \mathrm{~A}$ & $16.92 \mathrm{~A}$ & $3.85 \mathrm{~A}$ & $4.23 \mathrm{~A}$ \\
\hline \multicolumn{10}{|c|}{ Interaction effects } \\
\hline Organic $\mathrm{m}^{3} / \mathrm{fed}$. & & & & & $\mathrm{O}_{5}: \mathrm{K}_{2} \mathrm{O}$ & & & & \\
\hline \multirow{4}{*}{10} & & $40.33 \mathrm{G}$ & $41.00 \mathrm{G}$ & $83.67 \mathrm{~F}$ & $80.67 \mathrm{G}$ & $9.14 \mathrm{I}$ & $8.96 \mathrm{I}$ & $2.29 \mathrm{I}$ & $2.24 \mathrm{I}$ \\
\hline & $50: 30: 50$ & $45.00 \mathrm{~F}$ & $50.33 \mathrm{E}$ & $85.67 \mathrm{EF}$ & $84.67 \mathrm{~F}$ & $10.45 \mathrm{G}$ & $11.55 \mathrm{G}$ & $2.61 \mathrm{G}$ & $2.89 \mathrm{G}$ \\
\hline & $100: 40: 80$ & $52.00 \mathrm{D}$ & $53.00 \mathrm{D}$ & $94.00 \mathrm{CD}$ & $101.00 \mathrm{D}$ & $13.25 \mathrm{E}$ & $14.51 \mathrm{D}$ & $3.31 \mathrm{E}$ & $3.63 \mathrm{D}$ \\
\hline & $150: 50: 110$ & $57.00 \mathrm{~B}$ & $56.00 \mathrm{BC}$ & $96.67 \mathrm{BC}$ & $104.70 \mathrm{C}$ & $14.92 \mathrm{BC}$ & $15.88 \mathrm{C}$ & $3.73 \mathrm{BC}$ & $3.97 \mathrm{C}$ \\
\hline \multirow{4}{*}{15} & & $42.00 \mathrm{G}$ & $42.67 \mathrm{G}$ & $86.00 \mathrm{EF}$ & $84.33 \mathrm{~F}$ & $9.79 \mathrm{H}$ & $9.75 \mathrm{H}$ & $2.45 \mathrm{H}$ & $2.44 \mathrm{H}$ \\
\hline & $50: 30$ & $48.33 \mathrm{E}$ & $53.33 \mathrm{D}$ & $87.67 \mathrm{E}$ & $87.67 \mathrm{E}$ & $11.49 \mathrm{~F}$ & $12.67 \mathrm{~F}$ & $2.87 \mathrm{~F}$ & $3.17 \mathrm{~F}$ \\
\hline & $100: 4$ & $54.00 \mathrm{C}$ & $55.33 \mathrm{C}$ & 94.67 B-D & $104.70 \mathrm{C}$ & $13.85 \mathrm{D}$ & $15.69 \mathrm{C}$ & $3.46 \mathrm{D}$ & $3.92 \mathrm{C}$ \\
\hline & $150: 50: 110$ & $58.33 \mathrm{AB}$ & $56.33 \mathrm{BC}$ & $96.33 \mathrm{BC}$ & $108.00 \mathrm{~B}$ & $15.23 \mathrm{~B}$ & $16.49 \mathrm{~B}$ & $3.81 \mathrm{~B}$ & $4.12 \mathrm{~B}$ \\
\hline \multirow{4}{*}{20} & 0:0:0 & $44.00 \mathrm{~F}$ & $45.00 \mathrm{~F}$ & $87.67 \mathrm{E}$ & $82.67 \mathrm{FG}$ & $10.45 \mathrm{G}$ & $10.08 \mathrm{H}$ & $2.61 \mathrm{G}$ & $2.52 \mathrm{H}$ \\
\hline & $50: 30: 50$ & $47.33 \mathrm{E}$ & $55.67 \mathrm{BC}$ & 93.33 D & $88.33 \mathrm{E}$ & $11.97 \mathrm{~F}$ & $13.32 \mathrm{E}$ & $2.99 \mathrm{~F}$ & $3.33 \mathrm{E}$ \\
\hline & & $54.67 \mathrm{C}$ & $57.33 \mathrm{~B}$ & $97.00 \mathrm{~B}$ & $108.00 \mathrm{~B}$ & $14.37 \mathrm{CD}$ & $16.78 \mathrm{~B}$ & $3.59 \mathrm{CD}$ & $4.19 \mathrm{~B}$ \\
\hline & $150: 50: 110$ & $59.00 \mathrm{~A}$ & $60.33 \mathrm{~A}$ & $100.30 \mathrm{~A}$ & $112.30 \mathrm{~A}$ & $16.04 \mathrm{~A}$ & $18.37 \mathrm{~A}$ & $4.01 \mathrm{~A}$ & $4.59 \mathrm{~A}$ \\
\hline
\end{tabular}

Values having the same alphabetical letter (s) in common, within each column, do not significantly differ, using the revised L.S.D. test at 0.05 level of probability

\section{Fruit quality characters:}

Respecting the main effect of chicken manure fertilization, results in Table (6) reflected that cucumber plants fertilized with $20 \mathrm{~m}^{3} / \mathrm{fed}$. provided significantly the highest values for TSS \% (Brix), vitamin C (Ascorbic acid), reducing, non-reducing and total fruit sugars during both seasons, except for reducing sugars during the first season which reflected insignificant effect by various organic treatments, compared to the other treatments. Referring to the NPK mineral fertilizer main effect, it is noticeable that there is a direct proportionate relationship between the applicated mineral fertilizer rates and the given traits. In other words, as NPK increases; the given traits' average values increase and vice versa; whereas, the highest rates of $\mathrm{N}: \mathrm{P}_{2} \mathrm{O}_{5}: \mathrm{K}_{2} \mathrm{O}(150: 50: 110 \mathrm{~kg} / \mathrm{fed}$.) brought about the highest average values for TSS \% (Brix), vitamin C (Ascorbic acid),
Chicken manure contains $2.27 \% \mathrm{~N}, 1.07 \% \mathrm{P}$ and $1.70 \mathrm{~K}$ (Table 2), in addition to these, it is, also, contains micro nutrients. It is a good source of organic matter $(59.28 \%)$ which acts as a store house of all plant nutrients including trace elements might have released them gradually and steadily and this contributed towards the balanced nutrition of crop which resulted in maximum fruit yield. The profound effect of both organic and inorganic fertilizers on yield of cucumbers outcomes may be attribute to impact of organic fertilizer as a source of slow releasing nutritive elements and rapid dissolved NPK elements as a mineral (inorganic) fertilizer represent a synergism of combination components that to be available for plants to improve the plants quantitative vegetative growth [leaf number/plant ,branches number plant and fresh weight of plants]. The obtained results are in agreement, more or less, with many studies found that the combination of mineral fertilization with NPK + chicken manure led to increase yield and yield components of cucumber plants such as those reported by Feleafel et al. (2014). 
micro-nutrients, which might have helped in the assimilation of carbohydrates and in turn synthesis of ascorbic acid (Bade et al., 2017).

Also, this result may be attributed to the synchronization of availability of the proper forms of nutritive elements via organic or mineral fertilization. In other words, organic manure mineralizes and uptake slowly, compare to the inorganic fertilization NPK which release readily to the plants. These findings could be accounted to the presence of nitrogen either in mineral or in combination with organic fertilization which could activate many enzymes having a direct effect on photosynthesis and might enhanced fruit sugars content or many enzymes involved in metabolism of sugars contents (Mottaghian et al., 2008).

Table 6. Average values of some chemical fruit quality characteristics of cucumber plants 'Merage F1' as affected by organic, NPK mineral fertilizers and their interaction during 2016/2017 and 2017/2018growing seasons.

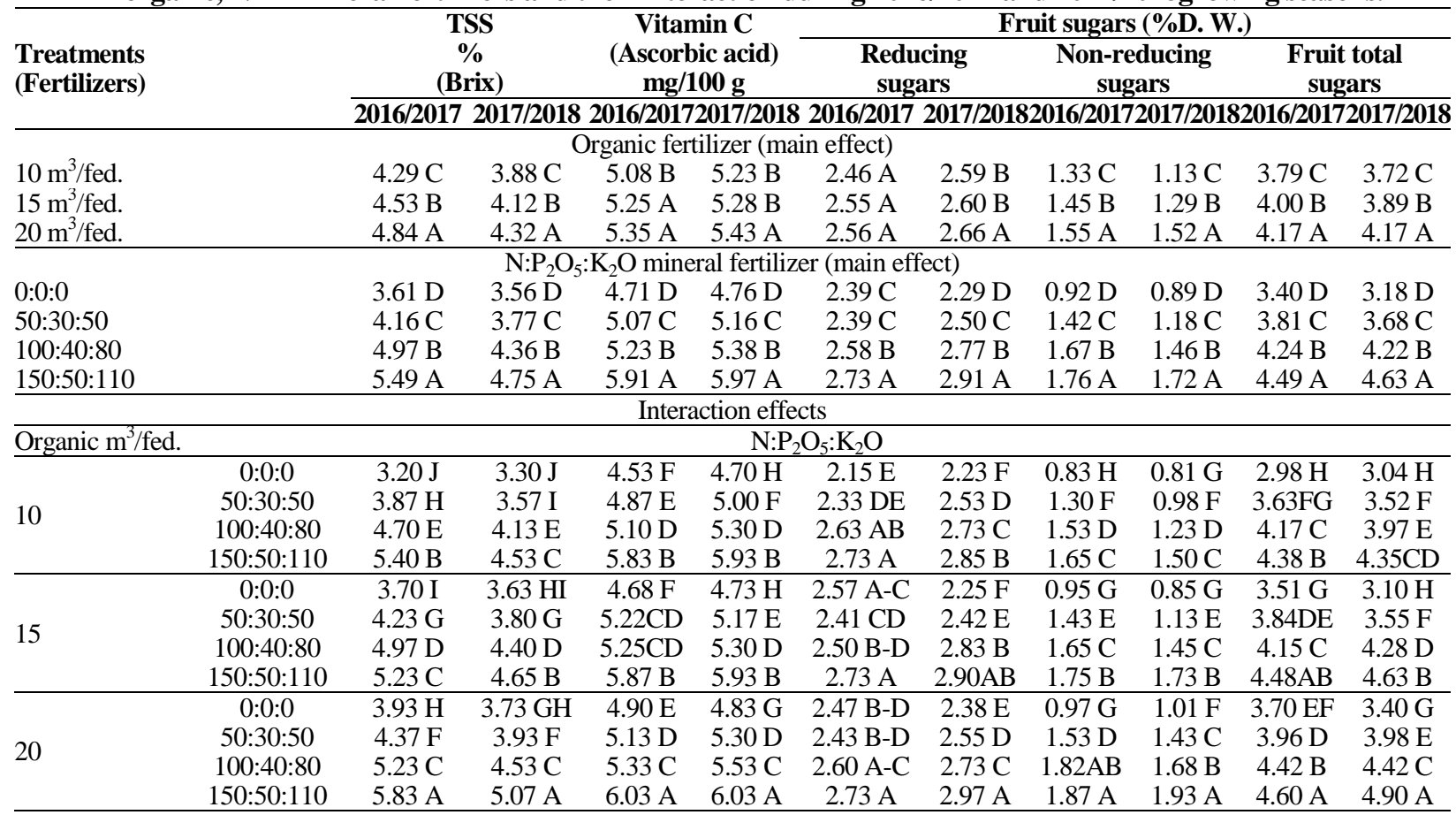

Values having the same alphabetical letter (s) in common, within each column, do not significantly differ, using the revised L.S.D. test at 0.05 level of probability.

4. Fruit chemical analysis:

Table 7. Average values of nutrient content of cucumber fruits 'Merage F1' as affected by organic, NPK mineral fertilizers and their interaction during 2016/2017 and 2017/2018 growing seasons.

\begin{tabular}{|c|c|c|c|c|c|c|c|}
\hline \multirow{3}{*}{$\begin{array}{l}\text { Treatments } \\
\text { (Fertilizers) }\end{array}$} & & \multicolumn{6}{|c|}{ Nutrient contents of fruits (\% d.w.) } \\
\hline & & \multicolumn{2}{|c|}{$\mathbf{N}$} & \multicolumn{2}{|c|}{$\mathbf{P}$} & \multicolumn{2}{|c|}{$\mathbf{K}$} \\
\hline & & 2016/2017 & $2017 / 2018$ & 2016/2017 & $2017 / 2018$ & 2016/2017 & $2017 / 2018$ \\
\hline \multicolumn{8}{|c|}{ Organic fertilizer (main effect) } \\
\hline $10 \mathrm{~m}^{3} / \mathrm{fed}$ & & $1.85 \mathrm{~B}$ & $1.72 \mathrm{C}$ & $0.44 \mathrm{~A}$ & $0.40 \mathrm{~A}$ & $1.31 \mathrm{C}$ & $1.68 \mathrm{C}$ \\
\hline $15 \mathrm{~m}^{3} / \mathrm{fed}$ & & $1.89 \mathrm{~B}$ & $1.84 \mathrm{~B}$ & $0.45 \mathrm{~A}$ & $0.42 \mathrm{~A}$ & $1.58 \mathrm{~B}$ & $1.82 \mathrm{~B}$ \\
\hline $20 \mathrm{~m}^{3} / \mathrm{fed}$. & & $2.04 \mathrm{~A}$ & $2.13 \mathrm{~A}$ & $0.46 \mathrm{~A}$ & $0.44 \mathrm{~A}$ & $1.83 \mathrm{~A}$ & $1.90 \mathrm{~A}$ \\
\hline \multicolumn{8}{|c|}{$\mathrm{N}: \mathrm{P}_{2} \mathrm{O}_{5}: \mathrm{K}_{2} \mathrm{O}$ mineral fertilizer (main effect) } \\
\hline 0:0:0 & & $1.43 \mathrm{D}$ & $1.51 \mathrm{D}$ & $0.40 \mathrm{C}$ & $0.37 \mathrm{~B}$ & $1.30 \mathrm{D}$ & $1.29 \mathrm{D}$ \\
\hline 50:30:50 & & $1.63 \mathrm{C}$ & $1.76 \mathrm{C}$ & $0.43 \mathrm{~B}$ & $0.40 \mathrm{~B}$ & $1.49 \mathrm{C}$ & $1.57 \mathrm{C}$ \\
\hline 100:40:80 & & $2.00 \mathrm{~B}$ & $1.94 \mathrm{~B}$ & $0.48 \mathrm{~A}$ & $0.44 \mathrm{~A}$ & $1.66 \mathrm{~B}$ & $1.88 \mathrm{~B}$ \\
\hline 150:50:110 & & $2.64 \mathrm{~A}$ & $2.38 \mathrm{~A}$ & $0.49 \mathrm{~A}$ & $0.47 \mathrm{~A}$ & $1.84 \mathrm{~A}$ & $2.47 \mathrm{~A}$ \\
\hline \multicolumn{8}{|c|}{ Interaction effects } \\
\hline Organic $\mathrm{m}^{3} / \mathrm{fed}$ & & & & $\mathrm{O}_{5}: \mathrm{K}_{2} \mathrm{O}$ & & & \\
\hline \multirow{4}{*}{10} & $0: 0: 0$ & $1.30 \mathrm{~J}$ & $1.40 \mathrm{I}$ & $0.37 \mathrm{D}$ & $0.34 \mathrm{E}$ & $1.04 \mathrm{H}$ & $1.20 \mathrm{H}$ \\
\hline & $50: 30: 50$ & $1.50 \mathrm{HI}$ & $1.60 \mathrm{H}$ & $0.41 \mathrm{CD}$ & $0.37 \mathrm{DE}$ & $1.17 \mathrm{G}$ & $1.50 \mathrm{~F}$ \\
\hline & $100: 40: 80$ & $2.10 \mathrm{D}$ & $1.70 \mathrm{G}$ & $0.48 \mathrm{AB}$ & $0.43 \mathrm{~A}-\mathrm{C}$ & $1.42 \mathrm{~F}$ & $1.83 \mathrm{D}$ \\
\hline & $150: 50: 110$ & $2.50 \mathrm{C}$ & $2.17 \mathrm{D}$ & $0.49 \mathrm{~A}$ & $0.46 \mathrm{~A}$ & $1.60 \mathrm{DE}$ & $2.20 \mathrm{C}$ \\
\hline \multirow{4}{*}{15} & 0:0:0 & $1.40 \mathrm{IJ}$ & $1.43 \mathrm{I}$ & $0.39 \mathrm{D}$ & $0.38 \mathrm{C}-\mathrm{E}$ & $1.33 \mathrm{~F}$ & $1.30 \mathrm{G}$ \\
\hline & $50: 30: 50$ & $1.63 \mathrm{G}$ & $1.70 \mathrm{G}$ & $0.43 \mathrm{~A}-\mathrm{D}$ & $0.39 \mathrm{~B}-\mathrm{E}$ & $1.53 \mathrm{E}$ & $1.60 \mathrm{E}$ \\
\hline & $100: 40: 80$ & $1.90 \mathrm{E}$ & $1.83 \mathrm{~F}$ & $0.47 \mathrm{AB}$ & $0.45 \mathrm{AB}$ & $1.63 \mathrm{D}$ & $1.90 \mathrm{D}$ \\
\hline & 150:50:110 & $2.63 \mathrm{~B}$ & $2.40 \mathrm{~B}$ & $0.48 \mathrm{AB}$ & $0.46 \mathrm{~A}$ & $1.83 \mathrm{C}$ & $2.47 \mathrm{~B}$ \\
\hline \multirow{4}{*}{20} & $0: 0: 0$ & $1.60 \mathrm{GH}$ & $1.70 \mathrm{G}$ & $0.42 \mathrm{~B}-\mathrm{D}$ & $0.40 \mathrm{~B}-\mathrm{E}$ & $1.53 \mathrm{E}$ & $1.37 \mathrm{G}$ \\
\hline & $50: 30: 50$ & $1.77 \mathrm{~F}$ & $1.97 \mathrm{E}$ & $0.46 \mathrm{~A}-\mathrm{C}$ & $0.43 \mathrm{~A}-\mathrm{D}$ & $1.77 \mathrm{C}$ & $1.60 \mathrm{E}$ \\
\hline & $100: 40: 80$ & $2.00 \mathrm{DE}$ & $2.30 \mathrm{C}$ & $0.48 \mathrm{AB}$ & $0.45 \mathrm{AB}$ & $1.93 \mathrm{~B}$ & $1.90 \mathrm{~B}$ \\
\hline & $150: 50: 110$ & $2.80 \mathrm{~A}$ & $2.57 \mathrm{~A}$ & $0.49 \mathrm{~A}$ & $0.48 \mathrm{~A}$ & $2.10 \mathrm{~A}$ & $2.73 \mathrm{~A}$ \\
\hline
\end{tabular}

Values having the same alphabetical letter (s) in common, within each column, do not significantly differ, using the revised L.S.D. test at 0.05 level of probability. 
As for the mineral fertilization main effect, the results showed that cucumber plants treated with 150:50:110 $\mathrm{Kg} /$ fed. $\mathrm{N}: \mathrm{P}_{2} \mathrm{O}_{5}: \mathrm{K}_{2} \mathrm{O}$; gave the highest nutrient content of fruits $(\mathrm{N}, \mathrm{P}$ and $\mathrm{K})$ during both seasons compare with the other treatments.

Regarding the interaction effects, the combination of $20 \mathrm{~m}^{3} /$ fed. chicken manure with 150:50:110 Kg NPK/fed; gave rise to the highest significant average values of the nutritional elements $(\mathrm{N}$ and $\mathrm{K})$ in cucumber fruits compared to the other treatments. Whereas, such clear effect not found for fruit $\mathrm{P}$ content. These results may be owned to the quick availability of $\mathrm{N}, \mathrm{P}$ and $\mathrm{K}$ elements of mineral fertilizer and the slow release of organic manure of nutrient constituents during the crop growth cycle which reflect on vegetative and reproductive organs (fruits).

This study recommends, generally, that the application of $20 \mathrm{~m}^{3} / \mathrm{fed}$. chicken manure with 150:50:110 $\mathrm{Kg} / \mathrm{fed}$. $\mathrm{N}: \mathrm{P}_{2} \mathrm{O}_{5}: \mathrm{K}_{2} \mathrm{O}$; resulted in the highest average values and might be considered as an optimal treatment for the production of high yield and good quality of cucumber plants 'Merage F1' hybrid under the environmental conditions of Aswan Governorate and other similar regions.

\section{REFERENCES}

A.O.A.C. (1992). Official methods of analysis of the association of official analytical chemistis, $15^{\mathrm{T}^{\mathrm{h}}} \mathrm{Ed}$. Published by the association of Official Analytical Chemists III. North Nineteenth suite 210 Arlington, Virginia 2220/U.S.A.

Abel, S., C. A. Ticconi and C. A. Delatorre (2002). Phosphate sensing in higher plants. Physio. Plant., 115: 1-8.

Ademola, O. and O. S. Agele (2015). Effects of nutrient sources and variety on the growth and yield of three cultivars of pepper (Capsicum annum 1.) in southwestern Nigeria. New York Sci. J., 8(10): 21-29

Adhikari, P., A. Khanal and R. Subedi (2016). Effect of different sources of organic manure on growth and yield of sweet pepper. Adv. Pl. Agric. Res., 3(5): 111-118.

Ahmed, M. E. M., A. A. A. Asem, A. Al Araby (2013). Growth, yield and fruit quality of sweet pepper plants as affected by some bioorganic and mineral fertilizers application. Life Sci. J., 10 (4): 2756-2766.

Alhrout, H. H. (2017). Response of Growth and Yield Components of Sweet Pepper to Tow Different Kinds of Fertilizers under Green House Conditions in Jordan. J. Agric. Sci., 9(10): 265-276.

Amalitois, D., I. Therios and M. Karatissiou. (2004). Effect of nitrogen fertilization on growth, leaf nutrients concentration and photosynthesis in three peach cultivars ISHS, Acta Hort. 449:36-42.

Aminifard, M. H., H. Aroiee, M. Azizi, H. Nemati and H. Z.E. Jaafar (2013). Effect of compost on antioxidant components and fruit quality of sweet pepper (capsicum aпnиит L.). J.Cent. Eur. Agric., 14(2): 47-56.

Arisha, H. M. and A. Bardisi. (1999). Effect of mineral and organic fertilizers on growth, yield and tuber quality of potato under sandy soil conditions. Zagazig J. Agric. Res., 26 (2): 391-405.

Aritonang, S. P., E. Panjaitan and F. P. Tondang (2018). Cucumber plants (Cucumis sativus L.) growth and crop yield of chicken manure fertilized with plant spacing. IOP Conf. Series: Earth and Environmental Science. 130: 012045. doi :10.1088/17551315/130/1/012045
Bade, K.K., V. Bhati and V.B. Singh (2017). Effect of organic manures and biofertilizers on growth, yield and quality of Chilli (Capsicum annum) cv. Pusa Jwala. Int. J. Curr. Microbiol. App. Sci., 6(5): 2545-2552.

Baiyeri, P. K., G. T. Otitoju, N. E. Abu and S. Umeh (2016). Poultry manure influenced growth, yield and nutritional quality of containerized aromatic pepper (Capsicum annuum L., var 'Nsukka Yellow'). Afr. J. Agric. Res., 11(23): 2013-2023.

Block, G., B. Patterson and A. Subar (1992). Fruit, vegetables and cancer prevention: a review of the epidemiological evidence. Nutr. Cancer, 18: 1-29.

Bricker, B. (1991). MSTATC: A Micro Computer Program from the Design Management and Analysis of Agronomic Research Experiments. Michigan State University, USA.

Caralcantio, A. L., M. C. Oliveira, V. G. Florentina, J. A. dos Santos, F.F. Vierira and C.L. Cavalcanti (2010). Short cemmuni-Cation: Invitro assessment of erosive potential of energy drinks. Eur. Arch. Paediatr dent.; 11: 253- 255. (C.F.Abilio et al.2011. Rev. Odonto Cienc, 26(4) :310-314).

Dash, S. K., G. S. Sahu, S. Das, S. Sarkar, L. Tripathy, S. R. Pradhan and A. Patnaik (2018). Yield improvement in cucumber through integrated nutrient management practices in Coastal Plain zone of Odisha, India. Int. J. Curr. Microbiol. App. Sci., 7(2): 2480-2488.

Dauda, S.N.; F.A. Ajayi and E. Ndor (2008). Growth and yield of water melon (Citrulus lanatus) as affected by poultry manure application. J. Agric. Soc. Sci., 4: 121-124.

Daughtry, C. S. T., C.I. Walthall, S. K. Kim, D.E. Broun and J. E. McMurtrey (2000). Estimation corn leaf chlorophyll con concentration from leaf and canopy reflectance. Rem. Sens. Environ, 74: 229-239.

Deore, G.B.; A. S Limaye; B. M. Shinde and S. L. Laware (2010). Effect of novel organic liquid fertilizer on growth and yield chilli (Capsicum annuum L.). Society of Applied Sciences: Asian J. Exp. Biol. Sci. Spl: 15-19.

Dubey, A. K., D. Singh, P. S. Rajput, Y. Kumar, A. K.Verma and S. K.Chandraker (2017). Effect of NPK on plant growth, yield and quality of Capsicum (Capsicum annum L.) c.v. Swarna Under Shade Net Condition. Int. J. Curr. Microbiol. App. Sci., 6(3): 1085-1091.

El-Bassiony, A. M., Z. F. Fawzy, E. H. Abd El-Samad and G. S. Riad (2010). Growth, yield and fruit quality of sweet pepper plants (Capsicum аппиит L.) as affected by potassium fertilization. J. Am. Sci., 6 (12): 722-729.

El-Gizy, S. M. H. (1978). Effect of some fertilizer treatments on growth and yield of strawberries. M.Sc. Thesis. Fac. Agric. Ain-Shams Univ. Cairo, Egypt.

El-Rawy, K.M. and A.M. Khalf-Allah (1980). Design and Analysis of Agricultural Experiments. Mousel Univ., Iraq (In Arabic) 448 PP.

EL-Shimi, N. M. M., E. H. M. El-Badawy and H. I. Tolba (2015). Response of Sweet Pepper Plants to some Organic and Bio-fertilizers and its Effect on Fruit Yield and Quality. Middle East J. Agric. Res., 4(3): 435-445.

Field, C. and H. A. Mooney (1986). The photosynthesis nitrogen relationship in wild plants In: On the economy of plant from (Givnion T. J, Ed. Cambridge univ. press, 25-53).

Gomez, K. A., and A. A. Gomez (1984). "Statistical Procedures for Agricultural Research". John Wiley and Sons, Inc., New York.pp:680. 
Hartz, T. K., M. LeStrange and D. M. May (1993). Nitrogen requirements of drip-irrigated peppers. Horti. Sci., 28: 1097-1099.

Hsiao, C. and A. Läuchli (1986). Role of potassium in plantwater relation. In: Advances in plant nutrition 2nd ed., pp. 281-312., Tinker and A. Läuchli (eds.). Praeger, New York.

Jackson, M. L., (1967). "Soil Chemical Analysis Advanced Course" Publisher By the author, Dept. of Soils, Univ. of Wise., Madison 6, Wishensin, U.S.A.

Jamir, T., V. B. Rajwade, V. M. Prasad and C. Lyngdoh (2017). effect of organic manures and chemical fertilizers on growth and yield of sweet pepper (Capsicum anпиum 1.) hybrid indam bharath in shade net condition. Int. J. Curr. Microbiol. Appl. Sci., 6(8): 1010-1019.

Khan, A., S. N. M. Shah, A. Rab, M. Sajid, K. Ali, A Ahmed and S. Faisal (2014). Influence of Nitrogen and potassium levels on growth and yield of chilies. Int. J. Farming and Allied Sci., 3(3): 260-264.

Khandaker, M. M., F. Rohani, T. Dalorima and N. Mat (2017). Effects of different organic fertilizers on growth, yield and quality of Capsicum annuum 1. Var. Kulai (Red Chilli Kulai). Biosci., Biotech. Res. Asia, 14(1): 185-192.

Lego, M., D. Singh and S. Tsanglao (2016). Effect of different levels of NPK on growth, yield and economic of capsicum (Capsicum annuum l.) cv. asha under shade net house cultivation. Int. J. Agric. Sci. Res., 6 (4): 5-8.

Lester, G. E., J. L. Jifon and D. J. Makus (2006). Supplemental foliar potassium applications with or without a surfactant can enhance netted muskmelon quality. Hortic Sci 41(3): 741-744.

Majiid, H.; S. Minali; M. Almasi and Y. Mostofi (2011). Total Soluble solids, Titrable acidity and ripenicg index of tomato in various storage conditions. Aust. J. Basic. Appl. Sci., 5(12) :1723- 1726.

Malik, C. P. and M. B. Singh (1980). Plant Enzymology and Histo-Enzymology- A text Manual, PP. 276- 277, Kalyani Publishers, New Delhi, India.

Marschner, H. (1995). Mineral Nutrition of higher Plants. 2nd Ed. Academic. press, Harcourt Brace and Co. Publishers, London.

Maya, P., S. Natarajan and S. Thamburaj (1999). Flowering, Fruit characters and quality as influenced by spacing $\mathrm{N}$ and $\mathrm{P}$ in sweet pepper cv. California wonder. South India. Hort., 45 (314): 125-127.

Moran, R. and D. Porath (1980). Chlorophyll determinations in intact tissue using $\mathrm{N}, \mathrm{N}$-dimethylformamide. Plant Physiol. 65, 478-479.

Mottaghian, A., H. Pidashti, M. A. Bahmanyar and A. Abbasian (2008). Leaf and seed micronutrients accumulation in soybean cultivars in response to integrated organic and chemical fertilizer application. Pak. J. Biol. Sci. 11: 1227-1233.
Murphy, J. and P. Riley (1962). A modified single solution method for determination of phosphates in natural waters. Anal. Chim. Acta 27:31-36.

Ngwu, O. E. and V. N. Edeh (2018). Effect of varying rates of NPK 15:15:15 fertiliser on the physicochemical properties of the soil, growth and yield of cucumber, (Cucumis sativus L.). Intel. J. Plant \& Soil Sci., 25 (1): 1-7.

Okalebo, J. R., W. K. Gathua and P. L. Woomer (2002) Laboratory methods of soil and plant analysis: A Working Manual. $2^{\text {nd }}$ ed. TSBF-CIAT and SACRED Africa, Kenya.

Papendick, R. I., L. F. Elliot and J. F. Power (1987). Alternative production systems to reduce nitrates in ground water. Am. J. Alternative Agr., 11: 19-24.

Pregel, E. (1945). Quantitative organic micro analysis. 4th Ed. J. Chundril, London.

Ranganna, S. (1986). Handbook of Analysis and Quality Control for Fruit and Vegetable Products. 2nd Edn. McGraw-Hill Publishing Co. Ltd., New Delhi, Pages: 1112.

Roba, T. B. (2018). Review on the effect of mixing organic and inorganic fertilizer on productivity and soil fertility. Open Access Library J. 5, e4618. https://doi.org/10.4236/oalib.1104618.

Russo, V. M. (1991). Effect of fertilizer rate, application timing and plant spacing on yield and nutrient content of bell pepper. J. Pl. Nutr., 14: 1047-1056.

Shahein, M. M., S. F. El Sayed, H. A. Hassan and S. Abou-ElHassan (2015). Producing Sweet Pepper Organically Using Different Sources of Organic Fertilizers under Plastic House Conditions. Inter. Conference on Advances in Agric., Biol. \& Environ. Sci., July 22-23.

Singh, B. and J. Ryan (2015). Managing fertilizers to enhance soil health. International Fertilizer Industry Association, Paris, France, 1-24.

Singh, J., M. K. Singh, M. Kumar, V. Kumar, K. P. Singh and A. Q. Omid (2018). Effect of integrated nutrient management on growth, flowering and yield attributes of cucumber (Cucumis sativus L.). Intl. J. Chem. Studies, 6 (4): 567-572.

Tucker, M. (2004). Primary nutrients and plant growth. In: Essential plant nutrients (Scribed, Ed.). Morth Carolina Dept. Agric.

Tumbare, A. D. and D. R. Niikam (2004). Effect of planting and fertigation on growth and yield of greenchili $(C$. annuum). Indian J. Agri. Sci., 74: 242-245.

Voth, V., K. Uriu and R.S. Bringhurst (1967). Effect of high nitrogen application on yield, fruit quality, and leaf composition of california strawberries. Proc. Amer. Soc. Hort. Sci., 91:249-256.

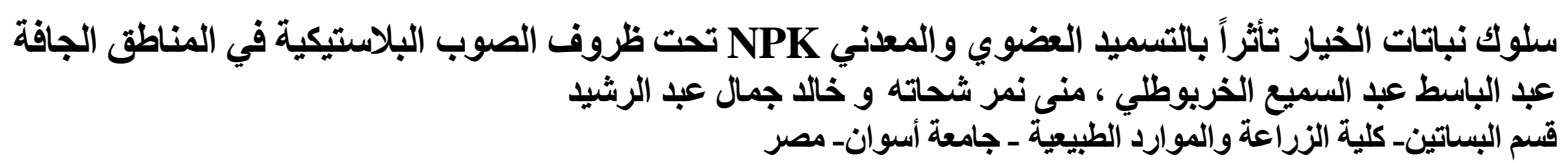

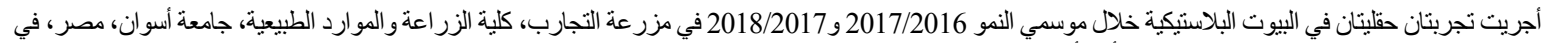

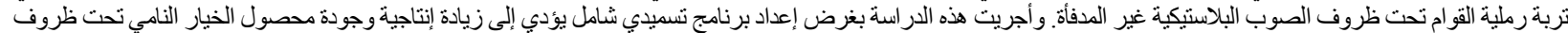

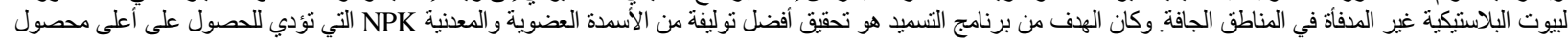

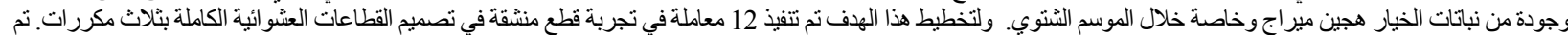

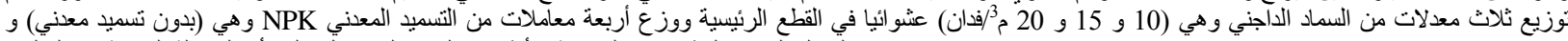

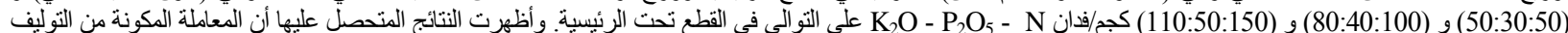

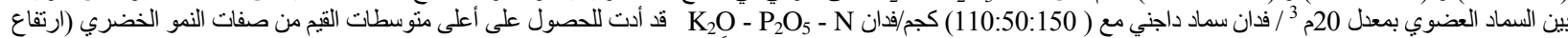

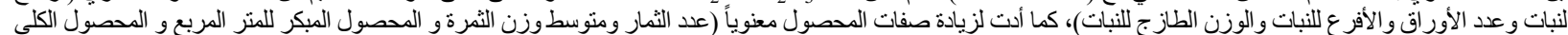

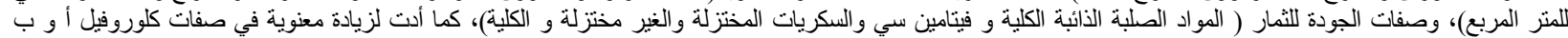

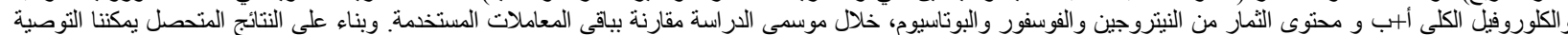

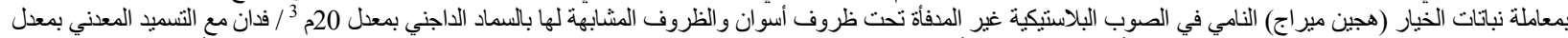

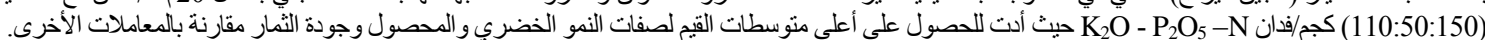

